\section{Great men and the mainstream}

History of Mankind: Cultural and Scientific Development. Volume 5. Parts I-IV: The Nineteenth Century. Edited by C. Moraze. Pp. 1,394. (George Allen and Unwin: London, 1976.) Parts I-II: £15; III: £15; IV: £15.

THIS curious 'volume' appears in three substantial tomes. The various chapters in it are written by various authors, or teams of authors; many of these are based in French institutions (other European countries being little represented) while others are from the USA, the USSR, and other nations. Sometimes the author is acknowledged at the top of his contribution, whereas for others one must search among the small type at the beginning of the first tome; no credit seems to be given to the translators, who have produced smooth versions of what were presumably papers for the most part not written in English.

The work is curious for various reasons; first because it was clearly written many years ago, as indeed is admitted in the preface where a date of "before 1960" is given. We are therefore getting a warmed-up hash, many parts of which have become obsolete long since; and it is even a half-baked hash, since the bibliographies have been omitted. By this tardy and incomplete publication, justice is hardly done to the various contributors, whose reputations will not be advanced by association with this project.

Even odder is the fact that the chapters were evidently sent to referees in various countries for comments; but were then published in their original form, with the referees' comments appended. Occasionally the author has commented on these comments, and his remarks also appear. The chapters are therefore accompanied by hostile annotations, often all too justified: but because of the omission of the bibliographies, we find dogmatic statements by the author and commentator; and cannot choose between them since we do not know on what evidence they are based. To publish an historical work without a proper account of the sources used is like publishing a scientific paper without any experimental details. Even for the illustrations, we are not always told where and when they were first published, although we are told which institutions made them available.

History was the province of a muse, and one might hope that a work of history would be a work of art; but if so, one would be disappointed with this volume, in which few of the chapters are written with any verve. Some con- tributors have an axe to grind-this can be a great help in an historical essay-but this usually leads only to the dullness of Marxist terminlogy; whereas others are preoccupied with the hopeless attempt to leave nothing out.

It is the first tome, dealing with the history of science and technology, to which readers of Nature are probably most likely to turn; and we can therefore examine it in more detail. In the introduction by the editor, abstractions chase one another in what is a completely schematic and impressionistic essay, being neither narrative nor detailed case study. When we come to mathematics and astronomy, we find the account is completely 'internal' and is moreover full of sentences of the kind: "Tom, Dick, and Harry also made important contributions to this field". The Russian referee made the point that any social dimension is completely lacking; and the same can be said of the other writings on the physical sciences, those on medicine and the life sciences being better though clearly out of date.

The narratives concentrate on great men and on the mainstream, and tend to lapse into the passive voice; there is little feeling that science is carried on by people called scientists, and that an important part of its history is the study of their collective behaviour. It was in the nineteenth century that science became a profession; that science became specialised, with the general journals of the academies being supplemented by those of societies catering for one science, or part of one; that formal courses in the universities leading to first and higher degree began; and that governments and industries began to employ scientists in large numbers as new legislation and new processes were introduced. This is not apparent from these internal accounts; which is not surprising, because the emphasis in the history of science has shifted in the past twenty years or so, away from accounts of how we got to where we are now, often written by superannuated scientists, towards attempts to recover how past science actually worked and what people were trying to explain or control. These essays are monuments, of varying quality, to an elderly and amateurish tradition; the most interesting is the critical note on the history of technology by Melvin Kranzberg.

In general, therefore, it is hard to see who would ever use this monument to international cooperation, and harder to see who one would recommend to use it.

David Knight

David Knight is a Lecturer in the History of Science at the University of Durham, $U K$.
New from Dont

\section{Konrad Lorenz}

\section{ALEC NISBETT}

'A distinguished populariser of science has tackled a fascinating life-story very well. With the fond detachment appropriate to ethology, Alec Nisbett makes the behaviour of its eccentric founder recognizably human in the richness of its roots and the contrariness of its motives. Nigel Calder 'An excellent biography . . . an incredibly fair picture of the man.' Desmond Morris, The Book Programme BBC TV

Illustrated with 16 pages of photographs $£ 5.95$

\section{Dating in Archaeology}

A Guide to Scientific Techniques STUART FLEMING

An invaluable account of all the methods (new and old) used in establishing the age of archaeological finds, for the art historian or archaeologist. $£ 8.95$

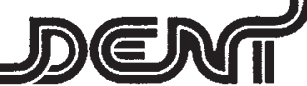

Circle No. 09 on Reader Enquiry Form. BOOKS ON PURE AND APPLIED SCIENCE

Books reviewed or mentioned in this journal are available from stock.

Catalogues on application.

Please state interests.

\section{SCIENTIFIC LIBRARY}

ANNUAL SUBSCRIPTION from $£ 5.00$ Reduced rates for multiple subscriptions Available in U.K. only

Prospectus free on request

\section{H.K. LEWIS \& Co. Lto. LONDON: 136 GOWER STREET, WC1E 6BS}

Telephone: 01-3874282 